\title{
Uterine Bacterial Isolates of Early Postpartum Endometritis and its Antibiogram
}

\author{
Leeba Chacko $^{1}$ *, K. Promod ${ }^{1}$, Chintu Ravishankar ${ }^{1}$, Hiron M. Harshan ${ }^{2}$, \\ C. P. Abdul Azeez ${ }^{1}$ and K. D. John Martin ${ }^{2}$ \\ ${ }^{1}$ Department of Veterinary and Animal Sciences, Pookode, Wayanad, Kerala- 673 576, India \\ ${ }^{2}$ Department of Veterinary and Animal Sciences, Mannuthy, Thrissur, \\ Kerala, India \\ *Corresponding author
}

\section{A B S T R A C T}

\begin{tabular}{|c|}
\hline Keywords \\
\hline $\begin{array}{l}\text { Endometritis, } \\
\text { Postpartum, } \\
\text { Antibiogram }\end{array}$ \\
\hline Article Info \\
\hline $\begin{array}{l}\text { Accepted: } \\
18 \text { July } 2020 \\
\text { Available Online } \\
10 \text { August } 2020\end{array}$ \\
\hline
\end{tabular}

Bacterial organisms causing endometritis at $31.58 \pm 0.13$ days postpartum in crossbred dairy cows were investigated along with in-vitro antibiotic susceptibility test of seven selected antibiotics viz., enrofloxacin, oxytetracycline, ciprofloxacin, metronidazole, gentamicin, cephalexin and ceftriaxone. The most frequently isolated bacteria in the present study were E. coli $(27.27 \%)$ followed by, Staphylococcus spp. (19.48\%), Bacillus spp. (18.18\%), Streptococcus spp. (15.58\%), Enterobacter spp. (11.69\%), Enterococcus spp. (5.19\%) and Pseudomonas spp. (2.60\%). Significant difference was noted in the sensitivity of different antibiotics $(\mathrm{p}<0.01)$. Sensitivity (Z-test) of ciprofloxacin was significantly higher than all other antibiotics under study. Heirarchichal cluster analysis of antibiotics under present study revealed highest sensitivity for ciprofloxacin $(88.31 \%)$ followed by enrofloxacin $(54.79 \%)$.

\section{Introduction}

Postpartum period has a great influence on the reproductive efficiency of dairy cows and any systemic or reproductive tract infections during this period will adversely affect future production and reproduction of the animal. The financial losses associated with severe uterine infections are due to reduced milk yield, infertility problems which leads to increased culling rate and cost of treatment involved.

Bacterial contamination of uterus at the time of parturition and early puerperium is inevitable in almost all the cattle in the herd and presence of bacteria in the uterine lumen could be detected during the first two weeks 
postpartum (Sheldon et al., 2006). Elimination of uterine contamination is crucial for timely involution of uterus and resumption of reproductive functions in dairy cows. Many of the cows spontaneously eliminate the contamination however, a delay in this process contributes to increased number of days open, more services per conception which in turn affect the reproductive efficiency of the herd. Bacterial invasion of uterus establish infection with resultant inflammatory changes of endometrium and its severity may vary depending on the type of organisms, duration of infection and the uterine layers which were affected and so on.

The most common bacteria associated with bovine endometritis were Escherichia coli, Arcanobacterium pyogenes, Fusobacterium necrophorum and Prevotella species. Indeed, A. pyogenes, F. Necrophorum and Prevotella spp. could act synergistically to enhance the chances for uterine diseases and increase the risk of endometritis (Olson et al., 1984; Ruder et al., 1981; Sheldon et al., 2002b). E. coli infection in the first week postpartum and $A$. pyogenes infection in the second week postpartum caused severe endometritis (Gilbert et al., 2007). The severity of endometritis depends upon the type of bacteria present, genetic factors, the innate and acquired immunity of the animal and a suitable uterine environment for bacterial growth (Williams et al., 2005). Several antibiotics such as tetracyclines, sulfonamides, aminoglycosides, $\beta$-lactams, fluoroquinolones and cephalosporins have been used either alone or in combination for the treatment of postpartum endometritis.

Bovine endometritis has been considered as the most common infertility problem of dairy cows incurring heavy economic loss to dairy industry and livestock farmers worldwide. Postpartum bacterial endometritis alters the normal cyclicity of cows, interferes with intrauterine transport of spermatozoa and embryo implantation, prolongs calving to first service and conception interval, increased services per conception and thereby decreases the conception rate (LeBlanc et al., 2002 and Hoelker et al., 2012). Hence, accurate and early diagnosis of endometritis is essential for successful treatment to improve reproductive efficiency in dairy cows.

\section{Materials and Methods}

The study was conducted at Instructional livestock farm, Pookode, Wayanad under Kerala Veterinary and Animal Sciences University and organized dairy farms of Wayanad district, Kerala. Crossbred dairy cows $(n=60)$ at 28-35 days postpartum, aged between three to eight years, parity between two to six without any history of postpartum reproductive complications, positive for endometritis by vaginal mucus score (Williams et al., 2005) were selected for the study. Cows which were treated with hormones, systemic or intrauterine antibiotic therapy in the current lactation was not included in the study group.

\section{Collection of samples by endometrial cytobrush}

Endometrial cytology samples were collected by cytobrush technique (Kasimanickam et al., 2005), with minor modifications. The human cytobrush (SteriUNO ${ }^{\circledR}$, India) was modified and fixed sharpened stylet of an artificial insemination (AI) gun. The assembly was inserted into an AI sheath covered by a sanitary plastic sleeve and sterilized by ultraviolet irradiation in a laminar air flow (Klenz Flo, India) for a period of $15 \mathrm{~min}$. The assembly was passed through the cervix and on reaching the uterus, the cytobrush was rolled on to the endometrium. The cytobrush assembly was taken out and the detached 
cytobrush placed in a sterile screw cap vial was transported to the laboratory on ice within two hours of collection and incubated for three hours at $37^{\circ} \mathrm{C}$ on brain heart infusion broth (HiMedia).

\section{Isolation and identification of bacteria}

After incubation, a loop full of the sample was inoculated on blood agar and incubated aerobically for $24 \mathrm{~h}$ at $37^{\circ} \mathrm{C}$. In the absence of growth, the plates were further incubated for $48 \mathrm{~h}$ at $37^{\circ} \mathrm{C}$ and examined for growth of bacterial colonies before declaring the sample bacteriologically sterile. Isolation and identification of bacteria based on the morphology and cultural characteristics were carried out as per Quinn et al., (1999). The morphological features of the bacterial organisms were studied by Gram's staining technique. Based on the results of Gram's staining, colonies were sub-cultured on Mac Conkey's agar (HiMedia) and incubated at $37^{\circ} \mathrm{C}$ for $24 \mathrm{~h}$ and growth characteristics were determined. Colonies suggestive of isolates were sub-cultured on brain heart infusion agar (HiMedia). For identification of bacteria, oxidase, catalase, indole, methyl red, Voges Proskuer, citrate utilisation, triple sugar, iron agar, urease, nitrate reduction and sugar fermentation tests were carried out. After the completion of morphological studies and cultural characteristics, the isolates were inoculated on nutrient agar slants and stored at $4^{\circ} \mathrm{C}$ and sub-cultured periodically to preserve the viability of the isolates. Individual isolates were inoculated in three milliliters nutrient broth and $500 \mu \mathrm{L}$ of defibrinated blood was added and mixed in a vortex shaker. Incubated it for two hours at $37^{\circ} \mathrm{C}$ and stored at $-20^{\circ} \mathrm{C}$ for long term storage.

\section{In-vitro antibiotic susceptibility test}

Antibiotic susceptibility tests were performed by disc diffusion method (Bauer et al., 1996).
Three to four isolated colonies were selected from a pure culture and transferred into sterile nutrient broth and incubated overnight at $37^{\circ} \mathrm{C}$. The turbidity of culture was adjusted using solution with half the density of Mac Farland standard No.1. Sterile Muller Hinton agar (HiMedia) plates with four millimeter depth were prepared and inoculated by swabbing over its entire surface, within 15 min. after adjusting the density of inoculum. Seven commercially available antibiotic discs $v i z$, enrofloxacin (EX $5 \mu \mathrm{g}$ ), oxytetracycline (O $30 \mu \mathrm{g}$ ), ciprofloxacin (CIP $5 \mu \mathrm{g}$ ), metronidazole (MT $5 \mu \mathrm{g}$ ), gentamicin (Gen $10 \mu \mathrm{g})$, cephalexin $(\mathrm{CN} 30 \mu \mathrm{g})$ and ceftriaxone (CTR 30 $\mu$ g) (HiMedia, Mumbai) were utilised to check the antibiotic susceptibility. The inoculated plates were incubated at $37^{\circ} \mathrm{C}$ for $18 \mathrm{~h}$. At the end of the incubation period, the plates were examined and the diameter of the zones of complete inhibition was measured in three different directions keeping the midpoint of the disc as the centre of the zone. The mean diameter of the zone of inhibition of each disc was compared with that of standard zone of inhibition chart provided by the disc manufacturing company and the isolates were grouped as resistant (R), fully susceptible (S) or intermediately susceptible (I) for each selected antibiotics.

\section{Statistical analysis}

The data obtained were subjected to statistical analysis as per the procedure described by Snedecor and Cochran (1994) using statistical software SPSS version 24.0.

Chi square test for multiple proportions followed by Z-test for testing the proportion of two different groups to test the sensitivity of different antibiotics. Hierarchical cluster analysis was done to identify the antibiotics with homogenous response. Results of the cluster analysis were represented by using dendrogram. 


\section{Results and Discussion}

\section{Isolation and identification of bacteria}

The bacterial organisms isolated from the uterine cytobrush samples of postpartum cows with apparent signs of endometritis at $31.58 \pm$ $0.13 \mathrm{dpp}$ are depicted in table 1 . The results of the present study revealed that the most predominant organism isolated from uterus of endometritis affected postpartum cows was $E$. coli $(27.22 \%)$ followed by Staphylococcus spp. (19.48\%) and Bacillus spp. (18.18\%). Baishya et al., (1998), Williams et al., (2007), Wagener et al., (2014), Crivei et al., (2016), Abreham et al., (2017) and Manimaran et al., (2019) reported E. coli as the major organism isolated from uterine infections. E. coli is considered as one of the earliest pathogen invading the uterus. LPS produced by $E$. coli impaired the hormonal balance and altered the resumption of cyclical activity (Williams et $a l ., 2008)$. Hence, control of $E$. coli infection could prevent endometritis at later postpartum period. While Abd El-Kader and Shehata (2001) reported Corynebacterium spp. while Bhat et al., (2013) and Liu et al., (2013) found Staphylococcus spp. as the main causative agent associated with postpartum uterine infection. The most common bacteria isolated were Streptococcus acidominimus and $E$. coli and the correlation between cytologic and bacteriologic findings was low (Baranski et al., 2012). Sens and Heuwieser (2013) found alpha-hemolytic Streptococcus to be strongly associated with reduced reproductive performance. Perusal of literature revealed that the uterine bacterial flora varied widely depending upon the stage of sampling, severity of infection, country and even differs with region of study. The majority of bacteria isolated from the uterus are opportunistic pathogen and host defense mechanism helps in combating the infection during early postpartum period. Immune state of the animal and the bacterial load played a key role in the development of uterine diseases in postpartum dairy cows (Sheldon and Dobson, 2004). Uterine infection is also a risk factor for delayed ovulation (Opsomer $e t$ al., 2000). Furthermore, ovarian function is perturbed in cows with uterine bacterial contamination after parturition (Sheldon et al., 2002). A recent study by de Boer et al., (2015) found that cows with any bacterial growth at 21 days after parturition, irrespective of bacterial species, were less likely to conceive.

\section{In-vitro antibiotic susceptibility test of uterine bacterial isolates}

The in-vitro antibiotic susceptibility pattern of different bacteria isolated from uteri of bovine postpartum endometritis cases with selected antibiotics were presented in table 2. The overall results of the in vitro antibiotic susceptibility test indicated that the maximum number of isolates were sensitive to ciprofloxacin $(88.31 \%)$, followed by gentamicin $(72.73 \%)$ oxytetracycline (63.64\%), enrofloxacin (54.79\%), ceftriaxone (25.97\%) and cephalexin (19.48\%). None of the isolates were sensitive to metronidazole. Chi square value indicates that there exists significant difference in the sensitivity of different antibiotics $(p<0.01)$. Z-test for testing the proportion of two different groups was done as pair wise comparison which revealed that the sensitivity of ciprofloxacin was significantly higher than all other antibiotics under study. No significant difference in the sensitivity was noted in the case of enrofloxacin, oxytetracycline and gentamicin. However, these antibiotics had significantly higher sensitivity as compared to cephalexin and ceftriaxone. Moreover, no significant difference in the sensitivity was observed between cephalexin and ceftriaxone.

Hierarchical cluster analysis was done for grouping the antibiotics with similar response. 
Results of the cluster analysis showing similarity in antibiotic susceptibility pattern of seven antibiotics namely enrofloxacin, oxytetracycline, metronidazole, ciprofloxacin, gentamicin, cephalexin and ceftriaxone given as dendrogram and were represented in Fig. 1. The antibiotics which showed less than 20 per cent variability in their response were grouped as homogeneous. Cephalexin and ceftriaxone showed almost similar pattern of response. Overall sensitivity of these two antibiotics were only 16.88 and 25.97 per cent, respectively. Hence, it could be concluded that they were similar only in terms of resistance and not in terms of sensitivity.

Ciprofloxacin and enrofloxacin exhibited only less than 15 per cent variability in their response while all the other antibiotics showed more than 20 per cent of variability. The percentage response revealed that ciprofloxacin exhibited 87.01 per cent sensitivity. Even though gentamicin recorded the second highest (72.73 per cent) sensitivity, dendrogram exhibited that the similarity between ciprofloxacin and gentamicin was less when compared to ciprofloxacin and enrofloxacin.

The cross tabulation between the response of isolates to enrofloxacin and ciprofloxacin revealed that among the 46 isolates which were sensitive to enrofloxacin, 45 isolates (97.80 per cent) were sensitive to ciprofloxacin also (Table 3). However, on cross tabulation between the response of the recovered isolates to ciprofloxacin and gentamicin, it was observed that among the 56 sensitive isolates of gentamicin, only 47 isolates ( 83.90 per cent) were sensitive to ciprofloxacin (Table 4).

Many other studies also supported the present finding of highest sensitivity for ciprofloxacin as 75 per cent (Moharana et al., 2000), 83.33 per cent (Ingawale et al., 2003), 93.75 per cent (Mane et al., 2009), 75 per cent (Reddy et al., 2012), 71.05 per cent (Bhat et al., 2013) while Nath et al., (2014) and Rohit et al., (2019) reported lower sensitivity of 45.90 per cent and 63.50 per cent, respectively than the present study. Zaman et al., (2015) also observed highest sensitivity for ciprofloxacin and enrofloxacin (100\%).

The overall sensitivity to oxytetracycline (63.64\%) reported in the present study was lower than that of Bhat et al., (2013) (71.05\%). While Reddy et al., (2012) observed that only 25.00 per cent of isolates were sensitive. Resistance to oxytetracycline was reported by Takamtha et al., (2013). Manimaran et al., (2019) reported that although gentamicin showed 100 per cent sensitivity to E. coli, the MIC observed indicate that oxytetracycline was more sensitive.

More number of isolates were sensitive for gentamicin than the current study as reported by Mane et al., (2009) (84.3\%), Malinowski et al., (2010) (96\%), Reddy et al., (2012) $(83.33 \%)$ and Bhat et al., (2013) (85.53\%). However, Kusam et al., (2008) reported lower sensitivity. Results comparable with the present study $(77.08 \%)$ were reported by Ingawale et al., (2003). Arora et al., (2000) also reported highest sensitivity for gentamicin. Contrary to the present study, Moharana et al., (2000) reported 79.16 per cent sensitivity for enrofloxacin, 75.36 per cent by Kusam et al., (2008), 91.67 per cent by Reddy et al., (2012), 73.68 per cent by Bhat et al., (2013), 73.53 per cent Joshi et al., (2013) and 60.32 per cent by Rohit et al., (2019) which were higher than observed in the present study $(54.79 \%)$. While Udayavel et al., (2013) observed lower sensitivity (32\%) to enrofloxacin. Bhat et al., (2013), Kavyashree (2013), Udhayavel et al., (2013) and Nath et al., (2014) reported that large number of isolates was sensitive to 
ceftriaxone $(67.11 \%, 40.26 \%, 64.00 \%$ and $89.20 \%$, respectively) than observed in the present study. Less number of isolates (10.17) were sensitive in the studies by Rohit et al., (2019).

The overall sensitivity for cephalexin reported in the current study (19.48\%) was lower than that of Kusam et al., (2008) and Takamtha et al., (2013) while higher than that of Reddy et al., (2012) and Bhat et al., (2013).

Quinolones rapidly inhibit DNA synthesis by promoting cleavage of bacterial DNA in the DNA-enzyme complexes of DNA gyrase and type IV topoisomerase, resulting in rapid bacterial death (Hooper, D.C., 1999). Fluoroquinolones are considered as the most efficacious antibacterials which include enrofloxacin, norfloxacin, ciprofloxacin, orbifloxacin, ofloxacin, danofloxacin, flumequine, difloxacin, marbofloxacin and other newer drugs. The quinolones inhibit the bacterial enzyme DNA-gyrase (topoisomerase), responsible for the supercoiling of DNA so that the DNA can twist in a number of chromosomal domains and seal around an RNA core. The quinolones are usually bactericidal therefore, susceptible organisms lose their viability within $20 \mathrm{~min}$ of exposure to optimal concentrations of the newer fluoroquinolones (Manoj et al., 2014).

The wide range of varying response to different antibiotics may be attributed to the variable environmental conditions, management system, condition of uterus of the animals under study and days postpartum. But, Devriese and Dutta (1981) reported that MIC of antibiotic as the only one important aspect in the in vivo situation than in vitro antibiotic testing.

In the current study, the most common bacterial species isolated from this region in the present study were E. coli and Staphylococcus spp. and the antimicrobial drug sensitive for majority of the isolates in this region was ciprofloxacin followed by enrofloxacin. The antibiotics selected for invitro antibiotic susceptibility studies were frequently used for uterine infections under in-vivo conditions. Also, identification of bacterial organisms causing uterine infection and adoptions of treatment measures is the ideal way for the treatment of uterine infection in postpartum animals. Rapid microbiological diagnosis is necessary for adoption of treatment under field conditions.

Table.1 Types of bacteria isolated from the uterus of cows with endometritis

\begin{tabular}{|l|l|c|}
\hline SI. No & Bacterial species & $\begin{array}{c}\text { Number of isolates } \\
\text { (per cent) }\end{array}$ \\
\hline $\mathbf{1}$ & Escherichia coli & $21(27.27)$ \\
\hline $\mathbf{2}$ & Staphylococcus spp. & $15(19.48)$ \\
\hline $\mathbf{3}$ & Bacillus spp. & $14(18.18)$ \\
\hline $\mathbf{4}$ & Streptococcus spp. & $12(15.58)$ \\
\hline $\mathbf{5}$ & Enterococcus spp. & $9(11.69)$ \\
\hline $\mathbf{6}$ & Enterobacterspp. & $4(5.19)$ \\
\hline $\mathbf{7}$ & Pseudomonas spp. & $2(2.60)$ \\
\hline & Total & $\mathbf{7 7}$ \\
\hline
\end{tabular}


Table.2 Sensitivity pattern of bacterial isolates from postpartum endometritis

\begin{tabular}{|c|c|c|c|c|c|c|c|c|}
\hline \multirow[t]{2}{*}{ Bacterial species } & \multirow{2}{*}{$\begin{array}{l}\text { Total } \\
\text { number of } \\
\text { isolates } \\
\text { (per cent) }\end{array}$} & \multicolumn{7}{|c|}{ Number of isolates sensitive } \\
\hline & & Enrofloxacin & Oxytetracycline & Ciprofloxacin & Metronidazole & Gentamicin & Cephalexin & Ceftriaxone \\
\hline Escherichia coli & $21(26.25)$ & 11 & 12 & 20 & 0 & 14 & 3 & 5 \\
\hline $\begin{array}{l}\text { Staphylococcus } \\
\text { spp. }\end{array}$ & $15(18.75)$ & 8 & 9 & 12 & 0 & 10 & 2 & 3 \\
\hline Bacillus spp. & $14(17.50)$ & 7 & 10 & 13 & 0 & 11 & 4 & 5 \\
\hline Streptococcus spp. & $12(15.00)$ & 9 & 8 & 10 & 0 & 9 & 3 & 3 \\
\hline Enterococcus spp. & $9(11.25)$ & 7 & 5 & 6 & 0 & 6 & 2 & 2 \\
\hline Enterobacter spp. & $4(5.00)$ & 3 & 3 & 4 & 0 & 4 & 1 & 1 \\
\hline Pseudomonas spp. & $2(2.50)$ & 1 & 2 & 2 & 0 & 2 & 0 & 1 \\
\hline Total isolates & 77 & 46 & 49 & 68 & $\mathbf{0}$ & 56 & 15 & 20 \\
\hline $\begin{array}{l}\text { Sensitivity } \\
\text { cent) }\end{array}$ & & $59.74^{b}$ & $63.64^{b}$ & $88.31^{\mathrm{a}}$ & 0.00 & $72.73^{b}$ & $19.48^{c}$ & $25.97^{\mathrm{c}}$ \\
\hline$\chi^{2}=115.716^{* *} ; p-v a$ & ue $<0.01$ & & & & & & & \\
\hline
\end{tabular}


Table. 3 Cross tabulation between enrofloxacin and ciprofloxacin

\begin{tabular}{|l|l|l|l|l|c|}
\hline \multicolumn{2}{|l|}{ Antibiotics } & \multicolumn{3}{|c|}{ Ciprofloxacin } & \multirow{2}{*}{ Total } \\
\cline { 3 - 6 } & & R & I & S & \\
\hline \multirow{3}{*}{ Enrofloxacin } & R & 1 & 4 & 3 & 8 \\
\cline { 2 - 6 } & I & 2 & 3 & 18 & 23 \\
\cline { 2 - 5 } Total & S & 1 & 0 & 45 & 46 \\
\hline
\end{tabular}

R-Resistant, I- Intermediate, S-Sensitive

Table.4 Cross tabulation between gentamicin and ciprofloxacin

\begin{tabular}{|l|l|c|c|c|c|}
\hline \multicolumn{2}{|l|}{ Antibiotics } & \multicolumn{3}{|c|}{ Ciprofloxacin } & Total \\
\cline { 3 - 6 } & & R & I & S & \\
\hline \multirow{3}{*}{ Gentamicin } & R & 1 & 1 & 10 & 12 \\
\cline { 2 - 6 } & I & 0 & 0 & 9 & 9 \\
\hline Total & S & 3 & 6 & 47 & 56 \\
\hline
\end{tabular}

R-Resistant, I- Intermediate, S-Sensitive

Figure.1 Dendrogram of antibiotics

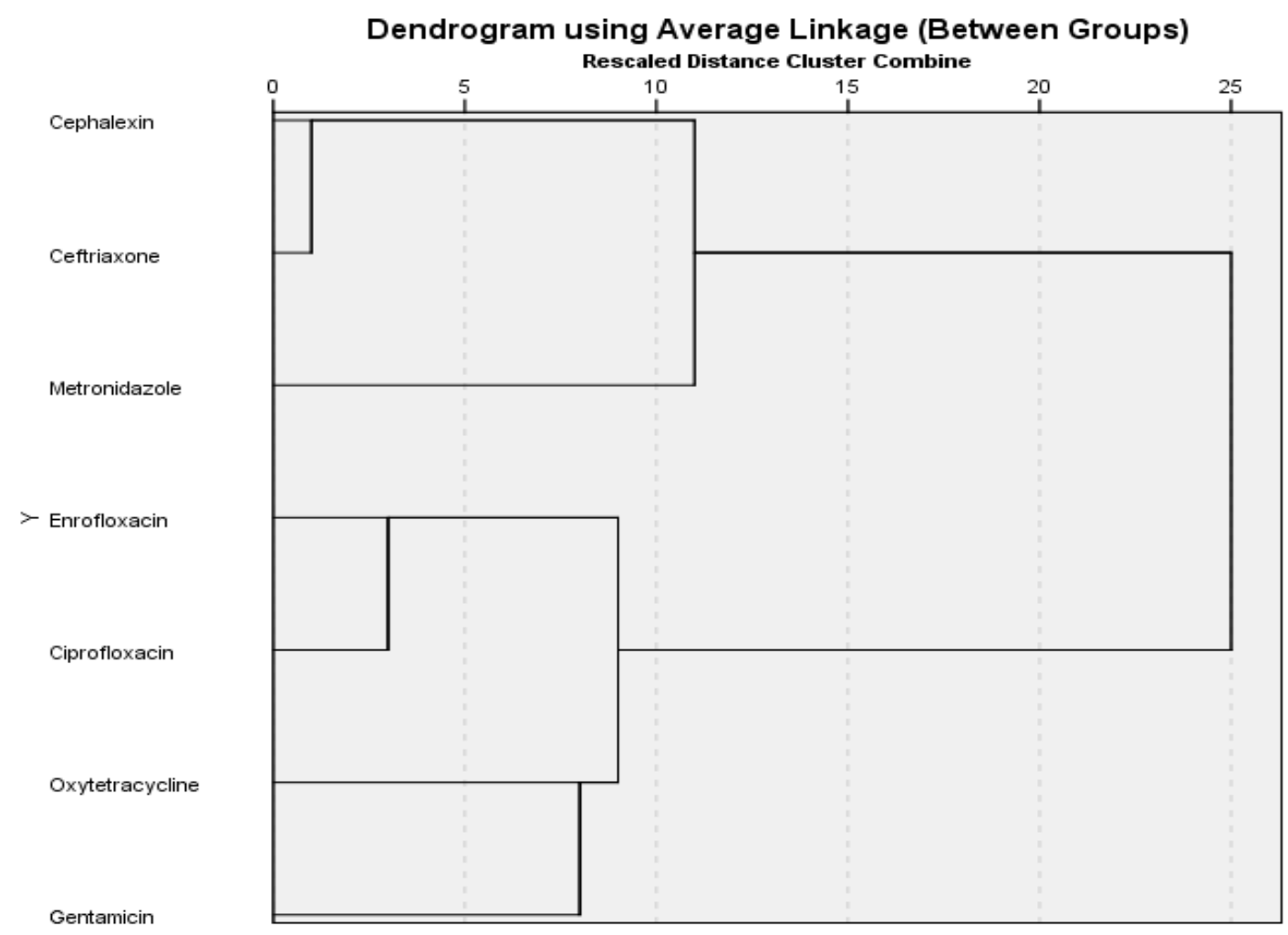




\section{References}

Abd El-Kader, H. A. and Shehata, S. H. 2001. Bacteriological Evaluation of Vaginal Discharges in Cows with Endometritis and Clinically Healthy Heifers In AssiutGovernorate. Ass. Univ. Bull. Environ. Res. 4:2.

Arora, A. K., Singh, J., Pangaonkar, G. R. and Nanda, A. S. 2000. Bacteriological studies on the genital infection in repeat breeder bovines. Indian J. Ani. Reprod.21: 146-147.

Baishya, S. K., Das, K. K., Rahman, H. and Borgohain, B. N. 1998. Antibiogram of bacteria isolated from uterine discharge of repeat breeding cattle. Indian $J$ Compar. Microbiol. Immunol. Infectious Dis. 19: 130-131.

Baranski, W., Zdunczyk, S. and Janowski, T. 2013. Reproductive performance of cows with subclinical endometritis diagnosed by different cytological thresholds in the postpartum period. Tierarztliche Praxis Ausgabe G: Grosstiere - Nutztiere. 41: 15-19.

Bauer, A. W., Kirby, W. M. M., Sherris, J. C. and Turck, M. 1966. Antibiotic susceptibility testing by a standardized single disk method. Am. J. Clinic. Patho. 45: 493-496.

Bhat F. A., Bhattacharya, H. K., Hussain, A., Nadeem, M. and Wani, A. R. 2013. Microbial profile, antibiogram and conception rate following treatment in repeat breeder cows. IntasPolivet 14: 4248.

Crivei, I. C., Cozma, A. P., Bors, S. I., Ruginosu, E., Roșca, P. and Drugociu, D. 2016. Antibiotics sensitivity of isolated bacteria from dairy cows with clinical endometritis. LucrariStiintificeUniversitatea de StiinteAgricole a Banatului Timisoara, Medicina Veterinara. 49: 26-32.

De Boer, M., Buddle, B. M., Heuer, C.,
Hussein, H., Zheng, T., LeBlanc, S. J. and McDougall, S. 2015. Associations between intrauterine bacterial infection, reproductive tract inflammation, and reproductive performance in pasturebased dairy cows. Theriogenology. 83: 1514-1524.

Devriese, L. A. and Dutta, G. N. 1981. Antibiotic sensitivity testing: correlations between in-vitro tests and in-vivo situations. Annales de Recherches Veterinaries. 12: 41-46.

Gilbert, R. O., Santos, N. R., Galvão, K. N., Brittin, S. B. and Roman, H. B. 2007. The relationship between postpartum uterine bacterial infection (BI) and subclinical endometritis (SE). J. Dairy Sci.90: 469-470.

Hoelker, M., Salilew-Wondim, D., Drillich, M., Christine, G., Ghanem, N., Goetze, L., Dawit, T., Schellander, K. and Heuwieser, W. 2012. Transcriptional response of the bovine endometrium and embryo to endometrial polymorphonuclear neutrophil infiltration as an indicator of subclinical inflammation of the uterine environment. Reprod. Fertil. Devel. 24: 778-793.

Hooper, D.C. 1999. Mode of action of fluoroquinolones. Drugs. 58: 6-10.

Ingawale M. V., Dhoble, R. L. and Sawale, A. G. 2003. Isolation, identification and antibiotic sensitivity pattern of the uterine secretions in the cows with metritis. Indian J. Ani. Reprod.24: 5253.

Joshi S., Mudasir, M., Sharma, D., Saraswat, N. and Singh, R. 2013. Bacterial microflora associated with repeat breeding in crossbred dairy cattle. Indian Vet. J.90: 52 - 54.

Kasimanickam R. T. F., Duffield, R. A., Gartley C. J., Leslie, K. E., Walton, J. S. and Johnson, W. H. 2005. A comparison of the cytobrush and uterine 
lavage techniques to evaluate endometrial cytology in clinically normal postpartum dairy cows. Canad. Vet. J. 46: 255-259.

Kavyashree S. 2013. Vaginal microbial flora of normal, repeat breeding and endometritis dairy cows. M. V. Sc. thesis submitted to the Karnataka Veterinary, Animal and Fisheries Sciences University, Bidar. pp 98.

Kusam K., Roy, G. P., Kunj, V. R., Asthana, K. and Akthar, A. H. 2008. Studies on uterine microbial isolates from endometric crossbred cows with reference to antibiogram, treatment and conception rate. Indian J. Ani. Reprod.29: 92-94.

LeBlanc S. J., Duffield, T. F., Leslie, K. E., Keefe, G. P., Walton J. S. and Johnson, W. H. 2002b. Defining and diagnosing clinical endometritis and its impact on reproductive performance in dairy cows. J. Dairy Sci.85: 2223-2236.

Liu, C., Wang, Y., Yang, Z., Cao, Y., Li, D., Liu, W. and Zhang, N. 2013. Prevalence and major pathogen causes of dairy cows clinical endometritis in Northeast China. Asian J. Ani. Vet. Adv. 8: 124129.

Malinowski E., Lassa, H., Markiewicz, H., Kaptur, M., Nadolny, M. Niewitecki, W. and Zietara, J. 2010. Sensitivity to antibiotics of Arcanobacterium pyogenes and $E$. coli from the uteri of cows with metritis/endometritis. Vet. J.30: 1-5.

Manoj, K., Pant, S.S., Ramsharan, R., Salendra, K. and Gupta, P. K. 2014. Therapeutic efficacy of levofloxacin along with vitamin $\mathrm{E}$ for the management of repeat breeding syndrome in cow under field condition. International J. Vet. Sc.3: 155-157.

Mane P. M., Dhoble, R. L., Chaudhari, R. J., Dawane, S. C. and Kolpe, A. B. 2009. Bacterial spectrum, antibiotic sensitivity pattern of bacterial isolates and conception rate in repeat breeders. Intas Polivet. 10: 32- 35.

Moharana, H. K., Pradhan, R. K., Patro, D. N., Sahoo, P. K., Nanda, S. K. and Mohanty, T. N. 2000. Antibiotic sensitivity studies on repeat breeder crossbred jersey cows in coastal districts of Orissa. Indian Vet. J. 77: .809-810.

Nath B. K., Das, B. C., Bari, M. S. and Rahman, M. A. 2014. Prevalence and risk factors of repeat breeding in commercial dairy farms of Chittagong district of Bangladesh. Int. J. Natural Sci.4: 21-27.

Olson, M. E., Ceri, H., Morck, D. W., Buret, A. G. and Read, R. R. 2002. Biofilm bacteria: Formation and comparative susceptibility to antibiotics. Can. J. Vet. Res. 66: 86-92.

Opsomer, G., Grohn, Y.T., Hertl, J., Coryn, M., Deluyker, H., de Kruif, A. 2000. Risk factors for postpartum ovarian dysfunction in high producing dairy cows in Belgium: a field study. Theriogenology. 53: 841-857.

Quinn, P. J., Carter, M. E., Markey, B. and Carter, G R. 1999. Bacterial pathogen, microscopy culture and identification. Text Book of Clinical Veterinary Microbiology. Mosby publication, New York. pp ed

Reddy, N. C. S., Bramhaiah, K. V., Naidu, K. S. and Kumar, R. V. S. 2012. Effect of uterine lavage on bacterial count and conception rate in repeat breeder crossbred cows. Indian J. Anim. Reprod. 33: 59-62.

Rohit, S., Madhumeet, S., Pravesh, K. and Akshay, S. 2019. In vitro antimicrobial sensitivity test and its efficacy in abandoned cows suffering from endometritis. Haryana Vet. 58: 37-39.

Ruder, C. A., Sasser, R. G., Williams, R. J., Ely, J. K., Bull, R. C. and Butler, J. E. 
1981. Uterine infections in the postpartum cow: II. Possible synergistic effect of Fusobacterium necrophorum and Corynebacterium pyogenes. Theriogenology. 15:573-580.

Sens, A. and Heuwieser, W. 2013. Presence of Escherichia coli, Trueperella pyogenes, alpha-hemolytic streptococci, and coagulase-negative staphylococci and prevalence of subclinical endometritis. J. Dairy Sci. 96: 63476354.

Sheldon, I. M., Noakes, D. E., Rycroft, A. N., Pfeiffer, D. U., Dobson, H. 2002b. Influence of uterine bacterial contamination after parturition on ovarian dominant follicle selection and follicle growth and function in cattle. Reproduction. 123: 837-845.

Sheldon, I. M. and Dobson, H. 2004. Postpartum uterine health in cattle. Ani. Reprod. Sci.82: 295-306.

Sheldon, I. M., Lewis, G., LeBlanc, S. and Gilbert, R. 2006. Defining postpartum uterine disease in dairy cattle. Theriogenology. 65: 1516-1530.

Takamtha, A., Phanaratkitti, V., Adirekkiet, O., Panyapornwitaya, V., Boonyayatra, S. and Kraeusukol. K. 2013. Prevalence of isolated bacteria from clinical endometritis uterus and antimicrobial susceptibility in postpartum dairy cows. Chiang Mai Vet. J.11: 237-245.
Udhayavel, S., Malmarugan, S., Palanisamy, K. and Rajeswar, J. 2013. Antibiogram pattern of bacteria causing endometritis in cows. Vet. World. 6: 100-102.

Wagener, K., Grunert, T., Prunner, I., EhlingSchulz, M. and Drillich, M. 2014. Dynamics of uterine infections with Escherichia coli, Streptococcus uberis and Trueperellapyogenes in postpartum dairy cows and their association with clinical endometritis. Vet. J.202: 527532.

Williams, E. J., Fischer, D. P., Noakes, D. E., England, G. C. W., Rycroft, A., Dobson, H., Sheldon, I. M. 2007. The relationship between uterine pathogen growth density and ovarian function in the postpartum dairy cow. Theriogenology.68: 549-559.

Williams, E. J., Fischer, D. P., Pfeiffer, D. U., England, G. C. W., Noakes, D. E., Dobson, H. and Sheldon, I. M. 2005. Clinical evaluation of postpartum vaginal mucus reflects uterine bacterial infection and the immune response in cattle. Theriogenology. 63: 102-117.

Williams, E. J., Herath, S., England, G. C. W., Dobson, H., Bryant, C. E. and Sheldon, I. M. 2008. Effect of Escherichia coli infection of the bovine uterus from the whole animal to the cell. Animal. 2: 1153-1157.

\section{How to cite this article:}

Leeba Chacko, K. Promod, Chintu Ravishankar, Hiron M. Harshan, C. P. Abdul Azeez and John Martin, K. D. 2020. Uterine Bacterial Isolates of Early Postpartum Endometritis and its Antibiogram. Int.J.Curr.Microbiol.App.Sci. 9(08): 1590-1600. doi: https://doi.org/10.20546/ijcmas.2020.908.xx 